Gut, 1962, 3, 201

\title{
Observations on idiopathic proctitis
}

\author{
J. E. LENNARD-JONES, G. W. COOPER, A. C. NEWELL, \\ C. W. E. WILSON, AND F. AVERY JONES
}

From the Research Department, St. Mark's Hospital, London

EDITORIAL SYNOPSIS This paper presents the natural history of idiopathic proctitis and concludes that this disease and idiopathic procto-colitis are two manifestations of one disease differing only in the extent of the colon involved.

There is some debate as to whether idiopathic granular or haemorrhagic proctitis is a local form of procto-colitis ('ulcerative' colitis). Further, the terms 'granular' and 'haemorrhagic' suggest that there is more than one form of idiopathic proctitis. In February 1951 a prospective study of patients with idiopathic proctitis was begun in the medical clinic at St. Mark's Hospital, and this report presents the findings in 100 patients seen during the first 10 years.

\section{DEFINITION}

For the purpose of this study, idiopathic proctitis is defined as an inflammatory condition of the rectal mucosa manifested clinically by abnormal sigmoidoscopic appearances described below: a clear upper limit beyond which the mucosa appears normal; an apparently normal colon on barium enema $x$-ray examination; and failure to identify a specific cause for the inflammation. This series comprises all patients who fulfilled these criteria when first seen in the medical clinic.

An upper limit to the disease was recorded at the first visit in 77 patients: in the other 23 patients an upper limit was not recorded at the first visit but was recorded within one month. In certain cases in this series barium enema examination suggested the presence of some muscle spasm in the sigmoid colon (N. P. Henderson, personal communication). Investigations, besides barium enema, included culture of the stools, microscopic examination of mucosal scrapings, mucosal biopsy, and serological tests when these appeared indicated.

\section{SOURCE OF CASES AND METHOD OF STUDY}

Patients were referred to the medical clinic by the surgical staff but not every case of proctitis seen at the hospital was referred. As St. Mark's Hospital deals only with diseases of the rectum and colon, and as only a proportion of cases of proctitis seen during the 10-year period was referred to the medical clinic, this series cannot be regarded as unselected.

Each patient's progress was followed wherever possible by direct observation or, failing this, by obtaining reports from other hospitals or the patient's doctor, or by postal contact with the patient. The source of the follow-up data at two and five years is shown in Table III. Sigmoidoscopy was usually performed at every visit to the clinic; barium enema was only repeated if clinical features suggested spread of the disease.

\section{RESULTS}

AGE OF ONSET AND SEX INCIDENCE This is shown in Fig. 1. For comparison, the age of onset and sex are also shown of 94 consecutive patients who attended the medical clinic during the same period with extensive procto-colitis involving the right or transverse colon and the whole of the remainder of the colon including the rectum.

FAMILY HISTORY OF PROCTO-COLITIS A family history was available in 97 cases, and of these, five patients

\section{TABLE I}

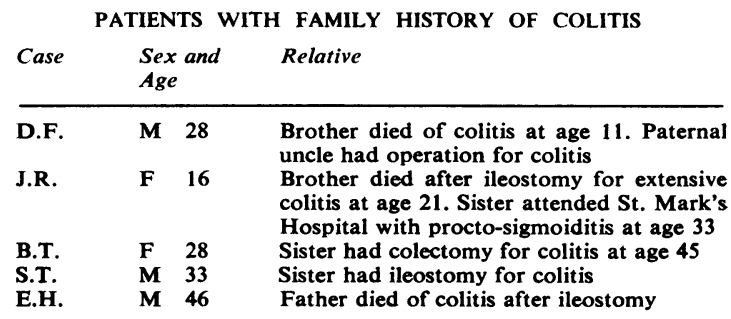




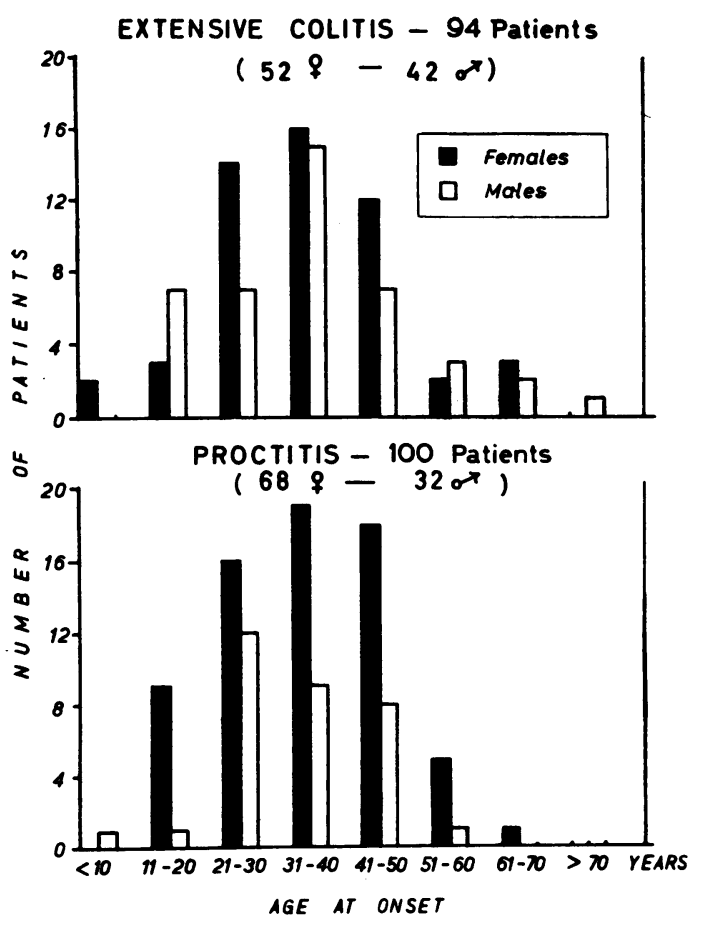

FIG. 1. The age of onset and sex incidence in proctitis compared to that in a consecutive series of patients with extensive colitis seen during the same time.

told us that near relatives had suffered from proctocolitis. Details are shown in Table I.

SYMPTOMS All but one of the patients complained of passing blood per rectum. Blood was often accompanied by other discharge and might be mixed with loose stools, streaked on solid stools, or passed alone with flatus. Enquiry revealed that frequent bowel actions, normal bowel habit, and constipation were each experienced by about one third of the patients during an attack (Table II).

TABLE II

BOWEL HABIT OF PATIENTS DURING AN ATTACK OF PROCTITIS

Symptoms

No.

Passage of one or more loose stools daily ${ }^{1}$

Passage of more than one formed or semi-formed stool daily

Normal bowel habit

Constipation with hard and/or infrequent stools

Irregular bowel habit

${ }^{1}$ In some patients it was difficult to distinguish between the passage of loose stools and the passage of liquid discharge.

'Some patients first experienced constipation during the illness; others had been constipated for many years.

Other symptoms complained of spontaneously were abdominal pain (9), urgency of defaecation or rectal pain or discomfort (8), flatulence (3), low backache (2). Only 13 of the 100 patients complained of some systemic upset such as tiredness or loss of weight. Two patients developed erythema nodosum during the follow-up period.

SIGMOIDOSCOPIC APPEARANCES AT DIFFERENT STAGES The acute phase of the disease is characterized by a wet, glistening oedematous mucosa which bleeds readily on being touched and is streaked with opaque 'mucopus' and blood. As symptoms improve the mucosa appears drier, rough, and granular, without spontaneous bleeding but bleeding to the touch. Later the mucosa becomes dry, granular, and no longer friable. In somecases, if remission is prolonged, granularity becomes less and is replaced by the normal clear-cut vascular pattern, either patchily or completely. Inflammatory polypi may form. Ulceration of the mucosa is rarely, if ever, seen in this condition but may be simulated by patches of opaque mucus on the surface.

The variation in the sigmoidoscopic appearance from time to time, either with treatment or during spontaneous exacerbation and remission of the disease, has been studied in this series by analysing the changes seen in 56 of the 100 patients who were sigmoidoscoped at least five times. In 46 of the 56 patients the mucosa was oedematous and bled freely to light touch on one occasion and was granular and non-friable on another. In 28 patients the mucosa bled freely to light touch on one occasion, appeared granular and non-friable on another, and a 'normal' vascular pattern was present on a third occasion. The granular phase and normal vascular pattern, but no haemorrhagic phase, were seen at different times in seven patients. In only one patient was the mucosa haemorrhagic at every examination, and in only two patients was the mucosa granular and not haemorrhagic at every examination.

A sharp transition may be seen between oedematous friable mucosa extending upwards from the anus and the 'normal' vascular pattern higher in the rectum. In other cases there may be a transition zone of granularity separating the haemorrhagic mucosa below from the clear vascular pattern above, or the inflammation may be patchy, some areas appearing almost normal and others abnormal. The level of transition between abnormal and 'normal' mucosa may vary in any patient from time to time. In 21 of the 56 patients sigmoidoscoped at least five times the level of transition was less than $15 \mathrm{~cm}$. from the anal margin at every examination. In other patients an upper limit to the abnormal appearance was seen at the first visit; at a subsequent visit the mucosa might appear inflamed as far as could be reached with the sigmoidoscope. At later visits, a level of transition 
between abnormal and normal appearances might be seen again. Outside this series we have observed an upper limit to the inflammation in several patients with extensive procto-colitis as the disease passed into remission: we have also seen an upper limit to the inflammation early during relapses of established extensive procto-colitis.

PROGNOSIS The condition of our patients has been assessed two and five years after their first visit to the clinic. As the clinic was started in 1951 and this report was written in 1961, a two-year follow-up was possible for patients seen between 1951 and 1959 and a five-year follow-up for patients seen between 1951 and 1956. The most interesting data concern patients who attended the clinic with a short history of the disease as they are more likely to be representative of all cases of proctitis than those with a long history. In Table III, which presents the followup data, the patients are divided for this reason into groups according to the length of time they had had symptoms at their first out-patient visit.

From this table it can be seen that a five-year follow-up was possible in 39 patients. Of these, two patients developed typical ulcerative colitis involving the whole colon and three patients developed colitis involving the left side of the colon. There was one death from colitis. Colectomy was performed in three patients, one of whom suffered from disease confined to the rectum with stricture formation. Sixteen of the 39 patients had had symptoms for less than six months at their first visit; two of them developed generalized colitis and one of them died after colectomy.

A two-year follow-up was possible in 69 patients and three of them developed colitis. Out of 25 patients with an initial history of less than six months, two developed extensive colitis within two years.

The disease spread to involve the colon in three patients not included in the two- or five-year followup and one of these patients required colectomy. Brief details of all the patients in whom the disease spread or in whom surgical treatment was required are set out in Table IV.

PATHOLOGY Rectal mucosal biopsies obtained from five patients in this series were examined by Dr. B. Morson who reported that the appearances were indistinguishable from those seen in cases of extensive ulcerative colitis. In each case there was superficial mucosal ulceration, heavy infiltration of the mucosa with chronic inflammatory cells, and hyperplasia of lymphoid follicles. Crypt abscesses were present in three of the five biopsies.

In cases outside this series we have searched for spirochaetes as recommended by Shera (1953) and the findings will be reported separately.

\section{DIFFERENTIAL DIAGNOSIS}

During the 10-year period the following patients were seen with other conditions which might have been mistakenly diagnosed as idiopathic proctitis.

TABLE III

RESULTS OF FOLLOW-UP AND SOURCES OF INFORMATION

\begin{tabular}{llll} 
Five-year & Follow-up & & \\
\hline History & History & History & Total \\
$\leqslant 6 / 12$ & 7 mth. & $>1$ yr. & \\
mth. & to 1 yr. & &
\end{tabular}

Two-year Follow-up

History History History Total

$\leqslant 6 / 12 \quad 7$ mth. $>1$ yr. mith. to $1 \mathrm{yr}$.

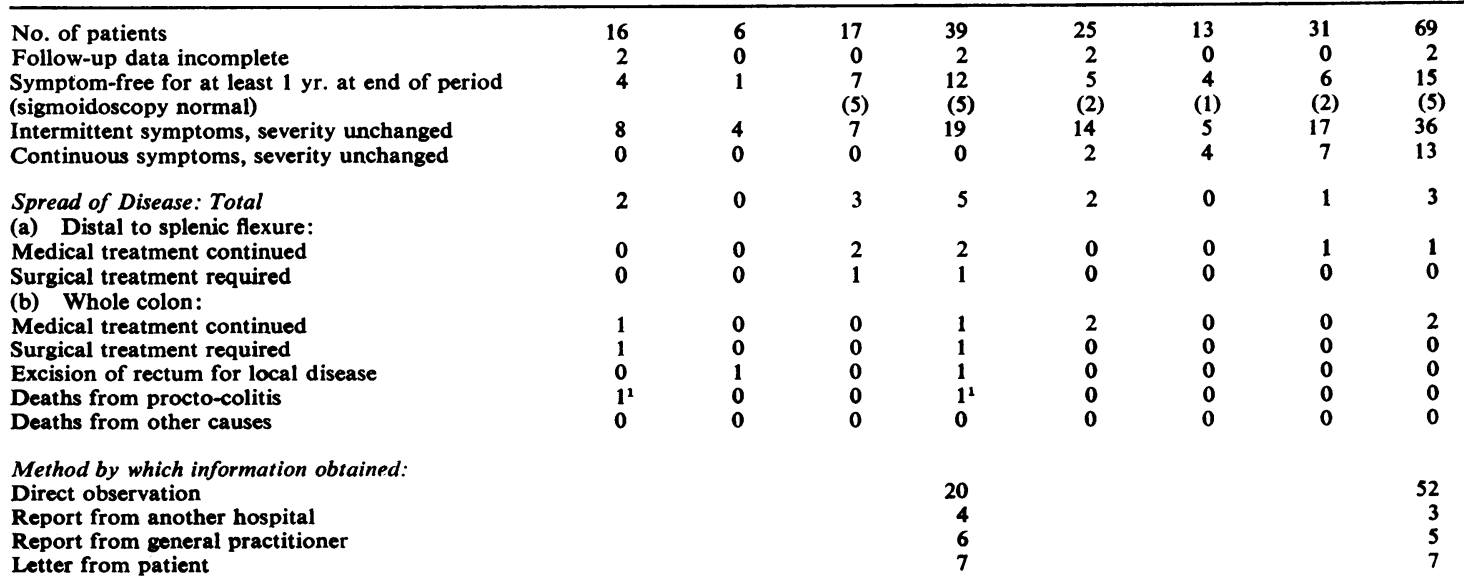

${ }^{1}$ Also included under spread to whole colon. 
TABLE IV

CLINICAL DETAILS OF PATIENTS IN WHOM DISEASE BECAME MORE EXTENSIVE OR WHO REQUIRED LOCAL SURGICAL TREATMENT

\begin{tabular}{|c|c|c|c|c|c|c|c|c|c|c|}
\hline \multirow{2}{*}{$\begin{array}{l}\text { Case } \\
\text { No. }\end{array}$} & \multirow{2}{*}{$\begin{array}{l}\text { Age of } \\
\text { Onset } \\
\text { and } \\
\text { Sex }\end{array}$} & \multirow{2}{*}{$\begin{array}{l}\text { Family } \\
\text { History } \\
\text { of } \\
\text { Colitis }\end{array}$} & \multicolumn{5}{|c|}{ Symptoms and Investigations at First Visit } & \multirow{2}{*}{$\begin{array}{l}\text { Time } \\
\text { between } \\
\text { Onset } \\
\text { and } \\
\text { Spread }\end{array}$} & \multirow{2}{*}{$\begin{array}{l}\text { Course of } \\
\text { Disease } \\
\text { between } \\
\text { Onset and } \\
\text { Spread }\end{array}$} & \multirow[t]{2}{*}{ Extent of Spread and Outcome } \\
\hline & & & $\begin{array}{l}\text { Bowel } \\
\text { Habit }\end{array}$ & $\begin{array}{l}\text { Systemic } \\
\text { Upset }\end{array}$ & $\begin{array}{l}\text { Length } \\
\text { of } \\
\text { History }\end{array}$ & $\begin{array}{l}H b \\
(\%)\end{array}$ & $\begin{array}{l}\text { E.S.R. } \\
\text { (Wintrobe) } \\
(\text { mm. })\end{array}$ & & & \\
\hline 18 & $28 \mathrm{M}$ & + & Normal & No & $8 / 52$ & 90 & 5 & $3 \frac{1}{2} \mathrm{yr}$. & Intermittent & $\begin{array}{l}\text { Sudden spread to involve whole } \\
\text { colon with severe systemic illness } \\
\text { and haemorrhage. } \\
\text { Died after colectomy. }\end{array}$ \\
\hline 33 & $51 \mathrm{~F}$ & - & $\begin{array}{l}\text { Consti- } \\
\text { pated }\end{array}$ & No & $6 / 52$ & - & - & 3 mth. & Continuous & $\begin{array}{l}\text { Spread to involve whole colon } \\
\text { with pseudopolyposis. Medical } \\
\text { treatment. Free of symptoms } 5 \\
\text { years later. }\end{array}$ \\
\hline 53 & $31 \mathrm{~F}$ & - & Normal & No & $4 / 12$ & 94 & 18 & $1 \mathrm{yr}$. & Continuous & $\begin{array}{l}\text { Spread to involve whole colon, } \\
\text { severe diarrhoea and systemic } \\
\text { upset. Medical treatment. } \\
\text { Symptom-free } 4 \text { years later. }\end{array}$ \\
\hline 37 & $18 \mathrm{~F}$ & - & $\begin{array}{l}\text { Irregular } \\
\text { formed }\end{array}$ & No & $3 \mathrm{yr}$. & 76 & 15 & $5 \mathrm{yr}$. & Intermittent & $\begin{array}{l}\text { Spread to involve lower half of } \\
\text { descending colon. } \\
\text { In-patient medical treatment. } \\
\text { Well } 4 \text { years later. }\end{array}$ \\
\hline 23 & $43 \mathrm{~F}$ & - & $\begin{array}{l}4 \text { nor- } \\
\text { mal stools } \\
\text { daily }\end{array}$ & No & $2 \mathrm{yr}$. & 58 & 22 & $3 \mathrm{yr}$. & Intermittent & $\begin{array}{l}\text { Persistent ill-health, recurrent } \\
\text { diarrhoea. Severe anaemia. } \\
\text { Colectomy } 7 \text { years after onset. } \\
\text { Specimen: ulceration and nar- } \\
\text { rowing of sigmoid colon and } \\
\text { rectum, remainder of colon al- } \\
\text { most normal. }\end{array}$ \\
\hline 38 & $35 \mathrm{~F}$ & - & $\begin{array}{l}\text { Consti- } \\
\text { pated }\end{array}$ & No & $13 / 12$ & 82 & 10 & $4 \mathrm{yr}$. & Intermittent & $\begin{array}{l}\text { Spread to involve sigmoid colon. } \\
\text { Medical treatment. Well } 4 \text { years } \\
\text { later. }\end{array}$ \\
\hline 36 & $52 \mathrm{~F}$ & - & Normal & No & $7 / 12$ & - & - & $3 \frac{1}{2}$ yr. & Continuous & $\begin{array}{l}\text { Excision of rectum and colec- } \\
\text { tomy for rectal stricture, peri- } \\
\text { anal sepsis and chronicill-health. } \\
\text { Specimen, only rectum involved, } \\
\text { colon normal, no suggestion of } \\
\text { Crohn's disease. }\end{array}$ \\
\hline 63 & $30 \mathrm{M}$ & - & Normal & No & $6 / 12$ & 92 & - & $3 \mathrm{yr}$. & Intermittent & $\begin{array}{l}\text { Spread to involve pelvic colon. } \\
\text { Remission after in-patient medi- } \\
\text { cal treatment. }\end{array}$ \\
\hline 77 & $46 F$ & - & Normal & Slight & $2 / 12$ & 82 & 43 & $4 / 12$ & Continuous & $\begin{array}{l}\text { Spread to involve descending } \\
\text { colon. In-patient medical treat- } \\
\text { ment. Well } 2 \text { years later. }\end{array}$ \\
\hline 78 & $48 \mathrm{~F}$ & - & $\begin{array}{l}\text { Consti- } \\
\text { pated }\end{array}$ & No & $7 \mathrm{yr}$. & 80 & 29 & $7 \mathrm{yr}$. & Intermittent & $\begin{array}{l}\text { Constipation associated with } \\
\text { megacolon. Two months after } \\
\text { first visit required urgent in- } \\
\text { patient treatment. } \\
\text { Vigorous medical treatment un- } \\
\text { successful, continued bleeding } \\
\text { and high fever. } \\
\text { Colectomy } 3 \text { months later. } \\
\text { Specimen, disease confined to } \\
\text { sigmoid colon. }\end{array}$ \\
\hline
\end{tabular}

CARCINOMA OF RECTUM AND RECTO-SIGMOID JUNCTION Three patients were referred because the mucosa of the rectum appeared haemorrhagic and oedematous on first examination. In fact, this appearance was due to the presence of blood-stained discharge on the surface of normal mucosa and a carcinoma was found.

CROHN's DISEASE OF THE RECTUM Two cases were diagnosed.

Case $A$ A man of 32 gave a five-year history of diarrhoea and rectal bleeding, with a recent loss of $7 \mathrm{lb}$. in weight. His father had died after an operation for an inflammatory disease of the colon. (Details obtained subsequently from the hospital gave the cause of death as ulcerative colitis but there was no pathological confirmation of this diagnosis.) Sigmoidoscopy on two occasions revealed a low-grade proctitis with a clear upper limit to the disease at 10 to $14 \mathrm{~cm}$. A barium enema was normal. His condition changed little during the next year, when an anal fistula developed and was laid open. The histological appearances of a biopsy suggested tuberculosis. There was no response to antituberculous drugs or corticosteroids. A purulent proctitis and an indolent peri-anal wound persisted despite formation of a sigmoid colostomy. Six months later the rectum was excised: the other viscera appeared normal at laparotomy. Examination of the specimen revealed 
ulceration in the lower third of the rectum: the proximal sigmoid colon was normal. Histological examination showed the typical appearances of Crohn's disease. The patient remains in good health five years after operation.

Case $B$ A boy of 12 gave an eight-month history of passing one or two semi-formed stools daily without bleeding. An anal fissure and a peri-anal abscess with fistula formation had been treated surgically. He felt unwell and had lost weight. Sigmoidoscopy revealed a mild proctitis. A barium enema and barium meal with followthrough showed no abnormality. The $\mathrm{Hb}$ was $70 \%$ and E.S.R. $45 \mathrm{~mm}$. in one hour (Wintrobe). Biopsy of the fistula on three occasions showed giant cells highly suggestive of tuberculosis or Crohn's disease. Antituberculous drugs were given without benefit. Two years later the fistula remained unhealed.

RADIATION PROCTITIS A few weeks after radium treatment for carcinoma of the cervix a woman of 64 developed rectal discharge without alteration in bowel habit. Sigmoidoscopy revealed a proctitis with an upper limit to the disease at $12 \mathrm{~cm}$.; an ulcer could be seen on the anterior wall of the rectum. Symptoms persisted with decreasing severity for five years.

LYMPHOGRANULOMA INGUINALE A Jamaican aged 25 presented with a two-month history of constipation, rectal bleeding, and discharge. A proctitis involving the lower $4 \mathrm{~cm}$. of the rectum was present, together with an anal fistula and enlarged inguinal lymph nodes. A Frei test and a complement-fixation test to lymphogranuloma venereum were positive.

OTHER CONDITIONS Goligher (1961) mentions the following conditions in the differential diagnosis of proctitis; bacillary or amoebic dysentery, gonorrhoea, syphilis, schistosomiasis, actinomycosis, chemical or mechanical irritation, solitary ulcer of the rectum, ? tuberculosis, and ? antibiotic diarrhoea.

\section{DISCUSSION}

This series of cases is the largest so far published and from the data presented two conclusions seem warranted. First, idiopathic proctitis represents a local form of procto-colitis ('ulcerative' colitis), and second, the various forms of proctitis described represent different stages of one disease.

Some previous writers (Milligan, 1933; Thaysen, 1934; Brooke, 1953a; Hardy, 1953; Rice-Oxley, 1953; Cropper, 1955) have distinguished a relatively benign granular or haemorrhagic proctitis (or procto-sigmoiditis) from the generally recognized procto- (ulcerative) colitis. Distinctions between the two conditions have been based on differences in symptoms, constitutional upset, sigmoidoscopic appearance, histological findings, and prognosis. Some state that inflammation may, if rarely, begin in the rectum or recto-sigmoid and extend proximally up the bowel (Brooke, 1953b; Hardy, 1953; Rice3
Oxley, 1953) but even so maintain that a fundamental distinction exists between proctitis or proctosigmoiditis and procto-colitis. Other authors (Goligher, 1953; Naish, 1953; Hill, 1957; Truelove, 1959) regard any differences between these conditions as simply one of degree, there being no essential difference between them.

The present series of cases was carefully restricted to those with disease initially involving only the rectum. Our reasons for thinking that this proctitis is in fact a local form of procto-colitis are as follows:-

AGE OF ONSET AND SEX INCIDENCE This is very similar to that found in generalized procto-colitis. We have not confirmed Brooke's finding (quoted by Cropper, 1955) that the sex incidence is roughly equal in granular proctitis: on the contrary we find that the disease affects women about twice as commonly as men.

FAMILY HISTORY The frequency ( $5 \%$ in this series) with which a close relative suffered from generalized severe colitis may be significant but cannot be properly assessed until the frequency of colitis in the general population is known with more accuracy.

SYMPTOMS The fact that patients with proctitis usually experience no systemic upset and often have a normal bowel habit or are constipated can be ascribed to the distal and small area of bowel involved: differences in symptoms do not necessarily distinguish two disease processes.

SIGMOIDOSCOPIC APPEARANCES We agree with Goligher (1953) and Hardy (1953) that the sigmoidoscopic appearances in proctitis are similar to and usually indistinguishable from those seen in generalized procto-colitis. In our experience it is very rare to see ulceration in the rectum through the sigmoidoscope (ulceration is frequently simulated by beads of mucopus which can be moved with the tip of the instrument), even though histological examination of biopsy specimens usually reveals superficial ulceration. This failure to observe macroscopic ulcers is supported by examination of diseased colons removed at operation on account of severe colitis. In these specimens deep ulceration rarely involves the bowel distal to the sigmoid colon (Lockhart-Mummery, 1959).

PROGNOSIS Our follow-up data suggest that the inflammation spreads proximally up the bowel in $10 \%$ or more of cases. We have observed extension of the disease seven years after the first symptoms and patients in whom spread subsequently occurs 
cannot be separated in the initial stages from those in whom the disease has not so far progressed.

PATHOLOGY Our few observations support the findings of Truelove (1959), based on a large series of biopsies, that the histological appearances of rectal mucosal biopsies in proctitis and generalized proctocolitis are identical. We differ from Thaysen (1934) in finding crypt abscesses in proctitis just as in procto-colitis.

\section{CONCLUSIONS}

To conclude, we believe that there is no fundamental distinction between proctitis and generalized procto-colitis; differences between them can be ascribed to the small area of bowel involved in the one and the large area in the other.

Our observations on patients who were sigmoidoscoped on more than five occasions show that the appearance of the rectal mucosa changes from time to time. These changes explain the terms 'granular' and 'haemorrhagic' proctitis, which are not two conditions but two phases of one disease.
We thank particularly Mrs. M. H. Wallace and Miss M. Klein for their help in analysing the data and in the follow-up, and Nurse T. James for her help in the outpatient clinic.

\section{REFERENCES}

Brooke, B. N. (1953a). What is ulcerative colitis ? Lancet, 1, 1220-1225. (1953b). What is ulcerative colitis? Ibid., 2, 566-567.

Cropper, C. F. J. (1955). Idiopathic granular proctitis. Ibid., 1, 1253-1254.

Goligher, J. C. (1953). What is ulcerative colitis? Ibid., 2, 38.

(1961). Surgery of the Anus, Rectum, and Colon. Cassell, London. Hardy, T. L. (1953). What is ulcerative colitis? Lancet, 2, 88-89.

Hill, J. R. (1957). Ulceration of the rectum and terminal portion of the colon. A.M.A. Arch. Surg., 75, 1029-1035.

Lockhart-Mummery, H. E. (1959). Some aspects of the pathology of ulcerative colitis. Proc. roy. Soc. Med., 52, Suppl. (AngloAmerican Conference on Proctology), pp. 3-4.

Milligan, E. T. C. (1933). Contribution to discussion on the diagnosis of chronic diarrhoeas-The differentiation of granular proctocolitis from ulcerative procto-colitis. Ibid., 26, 1059-1061.

Naish, J. (1953). What is ulcerative colitis? Lancet, 2, 254-255.

Rice-Oxley, J. M. (1953). What is ulcerative colitis? Ibid., 2, 38.

Shera, A. G. (1953). A syndrome associated with intestinal spirochaetosis. J. clin. Path., 6, 327-328.

Thaysen, T. E. Hess (1934). Simple haemorrhagic proctitis and proctosigmoiditis. Acta med. scand., 84, 1-24.

Truelove, S. C. (1959). Suppository treatment of haemorrhagic proctitis. Brit. med. J., 1, 955-958. 